\title{
Article \\ Not-Talking/Not-Knowing: Autoethnography and Settler Family Histories in Aotearoa New Zealand
}

\author{
Carolyn Morris
}

Citation: Morris, Carolyn. 2022. Not-Talking/Not-Knowing:

Autoethnography and Settler Family Histories in Aotearoa New Zealand. Genealogy 6: 10. https://doi.org/ 10.3390/genealogy6010010

Received: 23 July 2021

Accepted: 7 January 2022

Published: 25 January 2022

Publisher's Note: MDPI stays neutral with regard to jurisdictional claims in published maps and institutional affiliations.

Copyright: (c) 2022 by the author. Licensee MDPI, Basel, Switzerland. This article is an open access article distributed under the terms and conditions of the Creative Commons Attribution (CC BY) license (https:// creativecommons.org/licenses/by/ $4.0 /)$.
School of People, Environment and Planning, Massey University, Palmerston North 4442, New Zealand; c.m.morris@massey.ac.nz

\begin{abstract}
Critical family history analyses have generated powerful insights into the history and ongoing workings of colonization by bringing to light forgotten family histories and reframing them as stories of colonialism. Such work unsettles the descendants of early colonizers by compelling them to acknowledge the ways in which they continue to benefit from the colonizing actions of their ancestors. My family were colonizers, and some not-very-distant ancestors were part of the first wave of "settlers" who dispossessed Māori of their land in coastal Taranaki. Where my family differs from the families of many writers in the critical family history field is that they remain almost to this day on the land first taken by our direct ancestors. The question I address is how these settler farmers deal with the fact that the land that is now theirs is only recently so, and only became so through acts of violent dispossession, and that the descendants of the original possessors of that land continue to live on the Coast. I argue that one way that settler-colonizers deal with this uncomfortable history is to erase it. The erasure of this history is accomplished through the simple but effective strategy of not-talking about it, which leads to not-knowing about it. This practice, I suggest is critical for the subjective security of settlers, and it remains a crucial strategy in ongoing practices of quotidian colonization. My analysis emanates from a critically reflexive exploration of my memories, of what I know and what I do not know about the history of the farm I grew up on, and demonstrates that autoethnography as a methodology is particularly useful for interrogating and breaking the silences about colonization that contribute to its perpetuation.
\end{abstract}

Keywords: colonization; memory; family history; autoethnography

\section{Introduction}

To uncover my and my family's connections to settler colonialism I do not have to go to LINZ ${ }^{1}$ to find out which parcels of farmland my ancestors acquired after they immigrated and before they moved to urban centers (a common trajectory). I haven't had to painstakingly search Papers Past for traces of my forebears and their peregrinations. I do not have to spend time tracking down those (usually avoided) distant relatives who are obsessed with the not very interesting history of our very ordinary family to glean some details of the lives and personalities of my farmer forebears. I do not have to drive up and down sideroads looking for houses that look like the houses in old family photos, trying to figure out if that particular indistinguishable paddock was our paddock. My settler family history is not only a history but a present.

I know which blocks of land my ancestors acquired, I know the farmers who farmed them, and I know which house and which paddocks are ours since generations of my family did not move on to towns and cities, but settled into farming, on (or near) the land that they initially acquired. The passed farms on to sons, and expanded their holdings so there was enough land to pass on to more sons. Their daughters married the sons of similar farming families. In this way my family settled and spread and settled, resulting in a dense and extensive network of farmer kin. My family is a settler family, I am a settler. We are colonizers. Richard Shaw writes "I comfortably resort to the vocabulary of 
'settlement' rather than that of 'colonization'. In doing so, of course, I am engaging in one of the practices of forgetting" (Shaw 2021a, p. 7). I too feel more comfortable with being a settler, with its pleasant pioneering and arcadian intimations, than being a colonizer. But settler-farming is, as Campbell (2021) and Shaw (2021a, 2021b) so clearly show, a mode of colonization, and I think it useful to try to stick that term to those politics. In this paper I will use both terms, settler and colonizer, and when I use the terms settler, settling, settlement I am always referring to a mode of ongoing colonization.

I grew up on one of those multi-generational family farms. This farm, on Ngāriki Road, outside a small village in coastal Taranaki called Rahotu, was owned by my father (Buster Morris) and his brother (Uncle Pat) and before that my grandfather (L.B. Morris/Grandad), who bought it in $1927 .{ }^{2}$ I have no idea who he bought it from. His father (Fred Morris/Pop) farmed at Omata, further up the coast towards New Plymouth and his younger brother (Uncle Morrie) ended up on that farm. Grandad married Maggie Thomas (Nana), from a large Catholic farming family from up around Okato, and Dad married Maureen Radford, from another large Catholic farming family from Pungarehu. So, there are a lot of us. Most of my parents' siblings ended up owning farms or married farmers, and in time their sons inherited or bought those farms. Their daughters married the farmer sons of other farmers. So, I grew up on a farm occupied by my parents, my uncle and my paternal grandparents, surrounded by and engaged with numerous uncles and aunties and cousins on other farms.

I had a classic 1960s/1670s rural childhood. I spent quite a bit of time out on the farm (though I was never that keen on/encouraged to do much actual farm work, preferring reading), mucking about in the patch of bush up the back or down the river or in the drains or riding the motorbike pointlessly round and round the paddocks. We played with the puppies of farm dogs and fed calves. We played hide-and-seek across the farm at night. We built forts out of haybales (not allowed) and stole bottles of beer and drank them behind the hayshed. Mostly I did this with cousins. We did similar kinds of things when we went to our cousins' farms.

So my forebears acquired land and settled on it, and my family settled down and settled in, and as a result of all of this settling I was the fortunate beneficiary of a settled and secure (if at times boring) childhood. While not rich (the dairy boom came later) we were economically comfortable, and we were socially comfortable, embedded in family and community. We were also culturally comfortable, Pākehā people securely at home in a Pākehā world.

The land my forebears settled and that I played on and that provided me with security and comfort was of course alienated Māori land. By the time I came along New Zealand ${ }^{3}$ was well and truly settled by people who had come to be Pākehā. ${ }^{4}$ This settlement was simultaneously material and subjective; by the 1970s the land was securely in Pākehā hands and Pākehā were subjectively secure in their possession. ${ }^{5}$ But my settled life was predicated on the literal de-settlement of Māori, their removal from the land so that we could move in; my security - economic, social, cultural, subjective-necessitated the destruction of their security. This seems so obvious now, but as a child, and, to be honest, for an embarrassingly long part of my adulthood, I simply never thought about it. No one in my family talked about the history of the farm before Grandad bought it. We did not talk about him buying it. We simply owned it. The fact that Māori people had once owned that land and that a Māori world had been made on and with that land and then destroyed was "invisibilised" (Campbell 2021) - the history of that land and how it came to be my family's land had been erased from our conciousness. Writing of his farming family history, Hugh Campbell notes that "...we were able to farm peacefully and successfully precisely since other worlds had become invisible" (Campbell 2021, p. 7). It was the same for me.

When I shifted my gaze beyond the fences that demarcated a particular parcel of land as our farm, at the scale of farms-plural and at the scales of the village and the Coast, Māori were not invisible at all. Until the mid-1970s the farm next to ours was owned and farmed by a Māori family. There were many Māori children at school. There were some Māori teachers. They taught us basic words, such as colors and numbers, and we sang songs. We 
made tukutuku panels ${ }^{6}$ out of perforated hardboard, dowling, and raffia, we made poi ${ }^{7}$ out of wool and plastic, and we made sticks out of rolled up newspapers and sang while we played stick games. ${ }^{8}$ When we studied Māori culture in social studies the fathers of Māori kids in our class would put down a hāngī. When I was in form two, we stayed at Parihaka for a week and learnt about the history of Te Whiti and Tohu and their passive resistance and how they protested by ploughing up the land settlers were trying to settle and taking down their fences. ${ }^{9}$ I thought Te Whiti was cool. But I did not think about the fact that the settlers who Te Whiti, Tohu, and their followers were resisting were my forebears, and that I was their descendent and that I only lived on our farm since Parihaka was invaded and its resistance movement violently suppressed. We did not talk about the relationship of that past to our present, that was history. I have no idea what the Māori kids in the class knew and thought, since we did not talk about that.

There were Māori people in the local rugby and netball teams. There were Māori people in workplaces. Especially, Māori people worked at the dairy factory. In the haymaking season the factory boys came and picked up hay after their work at the factory was finished for the day. Sometimes they did this to make money for themselves and sometimes they were fundraising for the rugby club. There were marae dotted all along the coast. Some were quite big and I knew something about them, such as Parihaka. Most were small and I knew nothing about them and what went on there and who they belonged to. Sometimes I would see people and cars there when we drove along the road, so they were being used. There were also small cemeteries ${ }^{10}$ which were sometimes associated with marae and sometimes fenced off by themselves in the middle of Pākehā owned farms. People continued to be buried in them. So sometimes I got to glimpse that there was a whole other world in the place we lived. Māori people were very present, and their presence in the joint public worlds of Māori and Pākehā and in the interstitial spaces of marae and urupā, alluded to the fact that our land used to be their land. But we did not talk about that either.

This paper has two aims, one conceptual and one methodological. The first is to think about how this invisibilization of Māori was achieved and is maintained. I suggest that one of the key ways that this was and is carried out is by simply not-talking. I argue that not- talking, and the effect of not-knowing that not-talking produces, can be understood as one mechanism in the ongoing work of settler colonization. I use the terms not-talking and not-knowing rather than silence and ignorance deliberately. As a noun silence indicates the absence of sound, a kind of passive milieu. As a verb (as in silenced) it points to being stopped from speaking, and while the agency or action is with the silencer rather than the silenced, analytic emphasis tends to be on the effect on the latter. The term ignorance signifies a lack of knowledge, an absence, and, like silence, points towards passivity. Nottalking and not-knowing, by contrast, construct the not-talker and the not-knower as agents, making not-talking and not-knowing active. Didier Fassin suggests that what people say testifies to their agency as much as to their subjectivity (Fassin 2014, p. 69), i.e., that words may not reveal a self but are concerned with the work of world making, making something happen through a perlocutionary speech act, ${ }^{11}$ an attempt to shape what the hearer thinks and does. Extending this set of ideas, I suggest that we can usefully think of not-talking along these lines, as a kind of inverse perlocutionary act that works to create a world of not-talkers and not-knowers, and that what all of this not-talking attests to is the work and collective agency of Pākehā farmers in the reproduction of a world in which Māori are invisibilized.

Drawing on Connerton's (2008) concept of repressive erasure, I argue that not-talking is a strategy which works to suppress the knowledge that "our" farm was recently someone else's and that it might well not have been acquired through entirely fair and honourable means. This not-talking is critical for the making of subjective, cultural, social, and economic security for settlers like myself and my family. This not-talking, and the not-thinking and not-knowing that not-talking generates, was (and is) a fundamental strategy through which Pākehā settlement and settledness (as a mode of ongoing colonization) was and continues to be enacted. It is not the only mechanism through which this is carried out. But at the 
level of everyday life for ordinary Pākehā, and perhaps particularly for those who live in places where many Māori people (including the descendants of those who originally possessed our farms) still live, I suspect it might be a common one. As such, I decided to mine my memory and interrogate and reflect on what my family did and did not talk about and what I did and did not know about the history of the farm I grew up on before I did the work of actually finding out. I decided to draw an outline of what might have been erased and suppressed before I learnt, since once you know, you cannot un-know.

My second goal is methodological: to the historical and genealogical methodologies central to critical family history, I suggest that we can usefully add autoethnography, and that this cluster of methodologies might be particularly useful in situations where there is no historical break between your family's original settling and where you are settled now, that is, when dealing with settler family presents. If doing the detailed work of finding out about your family history enables you to refasten the broken links between yourself and your settler-colonist past and in doing so bring to light the mechanisms of linkbreaking that made forgetting possible, a critically reflexive autoethnography of memory and knowledge, undertaken by those whose links have not been broken, illuminates the ongoingness of the work and mechanisms of forgetting in the present.

\section{Critical Family History}

In her foundational work on critical family history, Sleeter $(2011,2016,2020)$ persuasively argues that family histories can be used to make audible what has been silenced in a nation's history, to bring into discourse "a silenced or suppressed national narrative" (Sleeter 2016, p. 11). Grounded in critical theory, critical race theory and critical feminist theory (Sleeter 2020, p. 64), critical family history "challenge[s] family historians to construct their histories in the context of social relationships forged through colonization, racism, and other relations of power" (Sleeter 2016, p. 14). As Shaw writes, "Its point is to lift the veil by explicitly connecting our small, intimate stories, with the large, sweeping forces that shape nations" (Shaw 2021a, p. 2). Doing this, critical family history scholars argue, is a potentially decolonizing move since the "social relationships that colonization forged, rather than being a relic of the past, live on in the present" (Sleeter 2016, p. 11). Thinking generally about history rather than exploring your own particular family history allows settler descendants to distance themselves from uncomfortable pasts, through disconnecting the past from the present. Critical settler family history, by contrast, compels you to confront the role of your own family in colonization and how you personally may continue to benefit from that legacy in the present (Sleeter 2016, p. 12; Bell 2020; Shaw 2021a, 2021b). This approach has the effect of compelling academics such as myself who are interested in colonization, Pākehāness and Māori/Pākehā relations to locate themselves firmly at the center of such analysis. Colonization is no longer an abstract, reified, agentless force, but something people you call Pop, Grandad, Dad, and Uncle Pat and I were and are engaged in.

A number of papers attest to the productiveness of the critical family history approach for thinking about the workings of settler colonization in Aotearoa New Zealand (e.g., Bell 2017, 2020; Campbell and Cuthers 2021; Hancock 2020; Fitzpatrick 2018; Shaw 2021a). Shaw's work is particularly relevant for my thinking, as the farms of his forebears were located only a few miles north of the farm I lived on, close to where my mother grew up. I knew one of his Gilhooly uncles, the fabulously named Tui Gilhooly (spoken always as a single word - Tuigilhooly). He was friends with my maternal grandfather and my father-I remember him sitting at the kitchen table drinking tea and talking. Such connections are not uncommon in a small country with a shallow settler history such as Aotearoa New Zealand and I have found the continuities and discontinuities in Shaw's and my experiences particularly good to think with. What these critical family histories show is how "small quiet stories" "may be more powerful than 'big' national stories" (Bell 2017, p. 456) in understanding colonization, and that connecting "very big stories" with "very little stories" (Shaw 2021a, p. 3) opens up ways for thinking about what decolonization might sound like. 
What these critical family histories of Aotearoa New Zealand also have in common is that for all of the writers they are histories (i.e., they themselves did not grow up on the land that their ancestors initially colonized; they are removed from that history, if only by a generation). As such, the material they analyze is the outcome of the painstaking work of genealogical research. My position, as someone who remained directly connected to the place of my family's original colonization, is a little different, and this difference makes a particular kind of autoethnography, an autoethnography of memory, possible.

\section{Autoethnography}

Sleeter herself notes the connections between autoethnography and critical family history: "autoethnography interrogates the self within a critical reflection of past experiences, using much the same data sources as family history" (Sleeter 2020, p. 64). Just as the small stories of family histories contribute to the assembling of big stories, it is individual experiences that make family histories (and family histories in turn shape individual experiences). As such the critically reflexive personal narratives that autoethnographic work produces have the potential to illuminate much more than individual subjective experience: "[o]ur lives are particular, but they are also typical and generalizable since we all participate in a limited number of cultures and institutions" (Ellis 1999, p. 674).

There is a body of literature that argues that autoethnography written by people who have been/are colonized "troubles the concepts and categories we breathe in, think through and live in" (Dutta 2018, p. 95). ${ }^{12}$ Analysis emanates from lived experience and as such makes audible the silenced voices of "the under-represented, oppressed, and marginalized" (Chawla and Atay 2018, p. 3). In this way autoethnography not only illuminates colonization but also "offers a critically reflexive tool for decolonizing" (Dutta 2018, p. 96). Drawing on the work of Frantz Fanon, Chawla and Atay explain how autoethnography can be decolonizing for both colonized and colonizer. The methodology provides a means for those colonized to speak back to colonizing power and simultaneously "addresses the colonizer, who must strive to achieve a degree of self-reflection, which illuminates the negative impact of colonization and what she has gained from it" (Chawla and Atay 2018, pp. 5-6).

Carolyn Ellis, one of the original writers on autoethnography, notes that doing such work can be challenging:

"The self-questioning autoethnography demands is extremely difficult. So is confronting things about yourself that are less than flattering. Believe me, honest autoethnographic exploration generates a lot of fears and self-doubts-and emotional pain... Then there's the vulnerability of revealing yourself, not being able to take back what you have written or having any control over how readers interpret it. It is hard not to feel your life is being critiqued as well as your work". (Ellis 1999, p. 672)

Writing as a settler/colonizer, Ellis' words speak to me and make me anxious. My autoethnography is unlikely to paint me in a flattering light. Writing in this way certainly makes me feel vulnerable. It has brought up emotions that I would rather not feel, and that I generally prefer to exclude from my academic world. What I write may well be read as self-indulgent and/or self-exculpatory, and in the future may seem embarrassingly naive (at best). If it is hard to be self-critical, it is very hard to be critical of Mum and Dad and Grandad and Nana and Uncle Pat.

If autoethnography allows the colonized to speak, it compels the colonizer to do so. As such it is a very useful methodology for the exploration of settler family presents. Adding autoethnography to critical family history is powerful since it draws attention to quotidian and mundane colonization, showing how the inequalities and inequities generated by settler colonization continue to be enacted and perpetuated through the practices of everyday life. By necessity based in critical reflection on a person's own experiences, autoethnography is perhaps particularly good for thinking about absences and silences, for accessing not-talking rather than talking, providing a platform from which to think about forgetting. 


\section{Forgetting and Remembering}

In critical family history research what is not said is as important as what is (Sleeter 2016, p. 13), the "absences and silences" (Shaw 2021a, p. 3) in family histories are as telling as what is present and spoken. Silences, however, are not simply the outcome of a lack of remembering: silences are deliberate, and their production is one of the ways in which settledness (as a subjective experience) is produced. Forgetting is a strategy, if not a conscious one. Connerton shows that "[f]orgetting is not a unitary phenomenon" (Connerton 2008, p. 59), and identifies seven modes of forgetting, including forgetting that is constitutive in the formation of a new identity (Connerton 2008, p. 62) and forgetting as repressive erasure (Connerton 2008, p. 60).

Forgetting that is constitutive of a new identity is a form of utilitarian forgetting, where "the emphasis ... is ... on the gain that accrues to those who know how to discard memories that serve no practicable purpose in the management of one's current identity and ongoing purposes" (Connerton 2008, p. 63). So, settlers forgot the humiliations and desperations that might well have been part of why they left their home country and forgot what had to happen (the alienation of the land of indigenous peoples) as a precondition for their new identity as prospering settler-farmers. Shaw (2021a) deploys this mode of forgetting in his analysis of his farming family history, arguing that his forebears forgot that they were poor tenant farmers in Ireland and forgot that the land they farmed was Māori land and that Māori had been violently dispossessed. They were able to forget and were able to pass that forgetting on down the generations so that Shaw does not have "to deal with the discomfort, politics and ethics of...[his] association with acts of violence and dispossession" (Shaw 2021a, p. 8). Shaw's mother had left the farm before he was born, and so his family were also able to discard, or at least create some distance from, a farmersettler identity, consigning their part in the agricultural mode of dispossession of Māori to the past (if a not very distant one).

I add a second mode of forgetting to think with, forgetting as repressive erasure. Connerton explains that repressive erasure "appears in its most brutal form ... in the history of totalitarian regimes, where, as in Milan Kundera's often quoted words, 'the struggle of man against power is the struggle of memory against forgetting'" (Connerton 2008, p. 60). Repressive forgetting is the abolition of memory, memory "consigned to oblivion" (Connerton 2008, p. 60). Many of the examples Connerton uses to explain this form of for-getting are forgetting on a grand scale, the forgetting of big stories. His examples show how a powerful state deliberately works to forbid or suppress public acts of remembering and in doing so works to erase collective memories of the past. He goes on to note that repressive erasure does not have to be so overt but can also be "encrypted covertly and without apparent violence" (Connerton 2008, p. 60). The example he gives is that of the art gallery which "presents the visitor with nothing less than an iconographic program and a master historical narrative; by walking through the museum the visitor will be prompted to internalize the values and beliefs written into the architectural script" (Connerton 2008, p. 60). As such, what is in a museum simultaneously and inevitably alludes to what is excluded and repressed.

I suggest that the idea of repressive erasure/forgetting can usefully be extended to think about not-talking about small stories as well as not talking about big stories. Nottalking about family history means family memory and individual memories are not made, and in time this not-talking produces a family script, which works as much through what is not talked about as what is talked about, and produces (in my case) a profound notknowing. In my family while forgetting as a constitutive of a new identity was a mode of forgetting (in that knowledge of the lives of my forebears came from in Britain was largely forgotten by the time I came along and there were no longer any connections to any family there), repressive forgetting was, I suggest, our dominant mode of forgetting. This might be since my farming family history is not only my family history but my family present. Writing in 2021, it is only six years since my father and uncle sold the farm I grew up on, and many members of my extended family continue to farm along the coast. 
Moreover, direct descendants of the original Māori possessors of those farms also, in all likelihood, remain. Maybe the ability to forget acts of dispossession is harder when you still dwell on that land. When your family has left the farms, you can more easily forget that you were a settler; being a colonizer is something that you were, not are. When you still dwell on that land, you need to work hard to forget. Especially when Māori are intent on publicly remembering.

\section{Not-Knowing Ngariki Farms}

I now turn to what I remember/know about Māori ownership of the land I always and only knew as "our farm" from my memories of growing up there, and from my decades of going home to visit my father. It turns out I remember almost nothing and that my memories are useless as a source of knowledge about the history of the farm. But, rather than doing the research to find out what the story actually was, in this paper I interrogate my memories to trace my not-knowing with the goal of shining some light on what nottalking and not-knowing do in the ongoing workings and work of settler colonization. What follows is a series of short vignettes. They represent the sum total of what I can remember being told, or what I gleaned, or what might have been obliquely indicated about the Māori people who, or whose forebears, possessed the land that had become my family's. Following these stories, I outline what I remember/know about the history of my farming forebears. What these stories attest to is the power of not-talking in making not-knowing. Racking my brain, I find I can only remember five stories about the relationships between Māori and the land that was my family's farm. These memories are so trivial they barely count as stories. The stories that refer to things other than my own experience might simply be wrong, and the things that I remember might be differently remembered by other people. They might not remember these things at all or they might have different, and contesting, memories. These fragments represent the sum-total of what I remember, what I knew and what I know. What they reveal is the depth and extent of my blithe and utter not-knowing.

\subsection{Story 1-The Mysterious House}

Across the road from my grandparents' house near the corner of Ngariki Road and the main road was a falling-down house. The paddock was not part of our farm but of the neighbor's farm and so it was not somewhere you could just go. Often there were steers or bulls in the paddock, so I never went into it. The house was mysterious and intriguing and pleasantly scary. I read Trixie Belden and Nancy Drew girl-detective stories and Enid Blyton's Famous Five and Secret Seven books, and some of their adventures involved mysterious abandoned buildings. Such mystery and adventure was scarce in my life. Our house had no cellar and no attic, there were no secret tunnels. If there were criminals, we did not recognize them, and they certainly were not catchable by children. I remember being told that an old Māori man used to live there. I think his name was Johnny Boardman, but that might not be right. Johnny Boardman might be someone else entirely. He might not even be Māori. Apparently, he was a good fella. I think he was around when Dad was young and used to do some work for my grandfather. But I might well be wrong about that.

\subsection{Story 2-The Stone Club}

Once I came across a stone club in one of the farm sheds. I did not know exactly what it was but I knew it was a Māori implement. It was made of grey stone and was about a foot long and was really heavy. I think it was found on the farm but I do not actually know where it came from. It was at our house for a while. I do not know what happened to it. I googled to see what it was. I think it was a pounder rather than a club.

\subsection{Story 3-Going to Heaven}

I remember being told this story by my mother. When I was very young, we lived in a house further up Ngariki Road from my grandparents' house and the cowshed. Down the road from us was a block of land that had a Maori cemetery on it. Apparently, I was 
asked where I wanted to go for a picnic one day, and I said I wanted to go to heaven. What had happened was that a Māori woman had died and had been buried in that cemetery. I had been told she had gone to heaven, and it seems like I thought that the cemetery was heaven and that it would be a nice place for a picnic. We obviously did not picnic there.

\subsection{Story 4-The Tauru Road Farm}

One of the farms next to ours was owned by a Māori family, the Renau family. When Dad and Uncle Pat bought it in the mid-1970s it was transferred into their ownership through "normal" market processes. Our family moved onto that farm, which was accessed from Tauru Road, the next road along from Ngariki Road. There was, however, a block of about ten acres between the two farms: they did not quite join up. Dad and Uncle Pat leased this block for a long time, I think they leased it before they bought the farm off the Renau family. At some point, they freeholded those ten acres, but I do not know when. I guess it made a difference to them, but it did not to me.

Moving to Tauru Road did not really change my life, but there were a couple of different things about this new farm. At one corner of the new farm there was a house on a section, where a Māori family lived. It was part of the ten acres block I think, and I noticed it since I passed it when I walked across to my grandparents' house. There was a flock of free-ranging geese there, and you had to keep a careful eye on them, since geese are scary. This house was not part of the farm, and it was unusual in that there were not many houses that were not farm houses outside of the village. In the middle of the farm there was a cemetery, which was still in use. I think this might have been the cemetery I thought was heaven. I do not remember ever seeing an actual funeral, but I do remember seeing Māori people going up the farm track to the cemetery, and sometimes cars full of Māori people I did not know would call at the house in relation to the cemetery and I found this a bit alarming. I think they were being polite and letting us know they were coming onto our farm. From my bedroom window I could see a small bush-covered hill on the neighbor's farm bordering our new farm, and I knew that this was also a cemetery. That Māori people were "allowed" to go onto "our" farm when they wanted was both normal (since it had a cemetery on it), and also a bit odd, since people did not usually go onto other peoples' farms.

\subsection{Story 5-My School Friend}

When I was about 10 or 11 years old a new girl came to our school. We became friends and she came to play a few times and came to one of my birthday parties. She was only at the school for a year or two, and then they went to live in New Plymouth (I think) and we did not keep in touch. It was harder to keep in touch back then and we were kids. She was related to the Renau family in some way, but I'm not sure how. When she came to play, she never mentioned that this had been her relatives' house and farm. Or I do not remember if she did. 13

So, this is what I remember about connections between Māori and our farms. Fragments amounting to almost nothing. My grandparents and Uncle Pat are dead, so I cannot ask them. My mother died when I was 12, so I cannot ask her. I did ask Dad about Johnny Boardman, but he is in a rest home and has vascular dementia and literally can no longer remember. ${ }^{14}$

\section{My Farm Family History}

If I know virtually nothing about the Māori connections to the farms that I grew up on, I also know virtually nothing about my migrating forebears. What were their lives such as in Britain? Why did they decide to migrate to the other side of the world? How did they end up in Taranaki? I do not know the answers to these questions since we did not talk about our family history either. This is what I remember/know. 
1. Grandad's forebears arrived in New Plymouth some time in the 1870s. They had a shop in Brixton, back when Brixton was a village outside London. This might not be true.

2. My great-grandfather, Pop Morris, was born in New Zealand. Grandad was born in 1904, so the maths work out okay. This might not be true. Pop might have been born in England.

3. They farmed at Omata, outside of New Plymouth. I do not know when they moved on to that farm. I do not know who they acquired it from.

4. When I was 12 or so there was some kind of family reunion in Collingwood, at the top of the South Island. So some forebears must have come from there. Dad's sister and my cousins went, but we did not. I am not sure how we got from there to Taranaki, or how I am connected to that particular genealogy. Somewhere I have the reunion booklet.

That is it. Since my grandfather bought the Ngariki farm himself, that is, it wasn't his family's farm, my great-grandparents did not live on this farm so there are no memories or stories of them from there. They are not associated with the Rahotu farm. From the time I can remember Pop lived in New Plymouth and Uncle Morrie was on the Omata farm, so I do not have any memories associated with that land. I do not feel like it is somewhere that I came from. So, the possibilities for the creation of a Rahotu family history, and the generation of memories from being on that farm, start in 1927, as do the processes of repressive erasure that institute forgetting.

\section{Colonizing the Coast}

What was the history that needed to be erased and forgotten? What did happen in coastal Taranaki? How did that land that used to belong to the Māori families whose kids I went to school with come to be owned by Pākehā farmers such as my family? As I have stated, I have not conducted the detailed work of tracing the history of the particular blocks of land that became my family's farms since my focus in this paper is on what I remember, and so the history I recount here is general. I take this history from the report of the Waitangi Waitangi Tribunal (2002) on the Taranaki claim. The report provides a devastating account of the intense, systematic and comprehensive process of dispossessing Māori and the transfer of ownership and control of the lands of coastal Taranaki to settlers. Dispossession was not a single event, but a long and many-pronged series of assaults. The methods were multiple: military action, confiscation, purchases (complicated, frequently dodgy and under conditions set by the colonial government), transformations in tenure, and farming - what Shaw calls the "agricultural campaign" (Shaw 2021a, p. 4). The logic, using the term as defined by Wolfe, was eliminatory (Wolfe 2006, p. 387), ${ }^{15}$ i.e., the removal of Māori from their land and its appropriation for settler occupation.

The official period of the Taranaki wars was 1860-1869, but military action continued until the invasion and destruction of Parihaka in 1881. Moreover, there was fighting in Taranaki long before 1860: " ... in Taranaki, conflict with the use of arms was spread not over a few months, as in most places, or even over a decade, but over a staggering 40 years" (Waitangi Tribunal 2002, p. 2). Confiscation followed, and though promises to return land to Māori were made they were not met. As a result, "many hapū were left with nothing of their own to live on and became squatters on Crown land" (Waitangi Tribunal 2002, p. 2). A portion of the land that was confiscated following military conquest was set aside as Māori reserves. However, collective title was extinguished and individual title imposed. Moreover, the now individually titled land was not returned to the control of those who owned it. Instead, the reserves were "given over to administrators to hold for Maori and 'the promotion of settlement'" (Waitangi Tribunal 2002, p. 2). The administrators then leased this land to settlers. These leases granted lessees the perpetual right of renewal, which in practical terms dispossessed Māori of their land, even if legal title had not been fully extinguished. ${ }^{16}$ Settlers paid rent for their leases but the amounts were paltry, and there were provisions in the legislation that encouraged the sale of land to 
settlers. Māori could apply to lease land "if they could show some farming capability" (Waitangi Tribunal 2002, p. 12). Prospective Mãori farmers had to pay rent even if they were an owner of the land, since title, though individualized, was multiple, so Māori lessees had to pay rent to their co-owners. Settlers were granted leases in perpetuity, with long periods between rent reviews, which made it possible for them to borrow money to develop the land. Māori lessees, by contrast, were granted only short-term "licenses to occupy" (Waitangi Tribunal 2002, p. 13), resulting in more frequent rent reviews, leading to higher rents, and foreclosing their ability to borrow to develop:

"The leases in perpetuity were the unkindest cut of all, the twist to the blade of the raupatu. It was not only that Maori lost a century of development experience. It was not only that with inflation and fragmentation the rents became as nothing. It was also that, as each generation of Maori succeeded to lands they could never walk on, they inherited the history of war, protest, imprisonment, and dispossession. They succeeded not only to lands under perpetual leases but to the perpetual reminder of forced alienation. As many witnesses and whole families protested at our hearings, they were denied even the right to forget. How could they forget when they saw their children leave home to seek work while they knew that the family land down the road would always be worked by strangers?". (Waitangi Tribunal 2002, p. 13)

Shamefully I never thought about how Māori people who lived on the coast, some of whom were people I knew, might feel seeing my family and others such as ours occupying and prospering on their land. We certainly did not talk about any of this. So, I did not know about it.

\section{Conclusions}

Patrick Wolfe writes that "settler colonization [is] a structure rather than an event" (Wolfe 2006, p. 390), by which he means that it is something that continues to happen, rather than something that happened in the past-tense of history, and that this happening is embedded in what in sociological shorthand we academics refer to as the structures of society. Settler colonization, he argues, is "an organizing principal of settler-colonial society rather than a one-off (and superseded) occurrence" (Wolfe 2006, p. 388). These organizing principles have become deeply embedded in institutions such as law and government, in structures of thought, and in social and cultural imaginaries. While they are deeply embedded, and, due to the ways we talk about them can seem prior to and outside of outside of human agency, they are in fact the outcome of hard and ceaseless human work at the most macro and micro of scales. As Bourdieu (2002) demonstrates, social structures have to be reproduced, and this is carried out through the ceaseless action of people as they labor to make what Hage (1998, p. 21) calls viable lives, lives of subjective security. Keeping lives and lifeworlds in place requires work, it requires labor, in the same way that changing lives and lifeworlds does. One form of the labor of reproducing colonization is a labor of erasing and invisibilizing Māori history and presence, and this is enacted at the micro-level of everyday farm family life through the ingenuous mechanism of simply not-talking about things. Not-talking results in not-knowing, an act of repressive erasure which produces a strategically useful form of ignorance in the generation of settled-settler subjectivity.

If not-talking/not-knowing is colonizing, what would happen if we talked and came to know? What would the perlocutionary effects of talking about the history of our farm be? What would happen if we found out how that land came to be our farm rather than the farm of the descendants of the original Māori possessors of that land? Could talking and knowing be decolonizing?

Working on the paper a few days after bashing out the ideas for the conclusion I see that I have stopped using the word "I" and have reverted to using the word "we". This has been the case throughout the various iterations of this paper-I constantly write "we" and have to go back and change it to "I". Who is the "we" I am interpolating when I use that word? On reflection, I think it is "We Pākehā". "We Pākehā" does include me, but what 
I see myself doing is retreating to the anonymity and safety of the collective, a linguistic strategy that allows me to distance my and my family's part in ongoing colonization. To be honest, I ended up writing autoethnography for this paper partly since I hadn't got around to doing the detailed genealogical research necessary to write about the actual history of the farms I grew up on as the deadline for submission approached. I did think it would be interesting and potentially illuminating to begin my work in the field of critical settler family history by exploring what I already knew. I thought it would be comparatively easy, and in one way it has been. I haven't gone to LINZ to trace the history of the ownership of the particular blocks of land that make up our farm. I haven't delved into the records of the Māori Land Court to find out who the owners of the ten acres that linked our two farms were, and how it came to be ours. I haven't spent hours exploring Papers Past. But in another way writing an autoethnography of my memory has been hard. I was stunned by the extent of my ignorance, embarrassed that I have never bothered to find out about my own particular history despite having lectured and written about Māori and Pākehā and racism and land. It turns out that I have been much more comfortable writing about other Pākehā or abstracted processes than about myself.

I recognize myself in Connerton's modes of forgetting and in the family strategies that Shaw (2021a) describes for himself. This recognition is not welcome. As someone who has now left the farm, I find myself tempted to separate my now-self from my childhood- farmself, to discard and ignore awkward elements as I constitute an academic anthropologist identity (non-racist, attuned to the impacts of colonization, politically progressive etc.). I find myself tempted to cast repressive erasure as something I did in the past. This is a very unsettling set of realizations, and I find myself resisting them (and being further unsettled by my resistance). I think this resistance is resistance to desettling myself, to becoming and being subjectively unsettled, to no longer being able to be a settler, a person subjectively and culturally secure. I do not want to think of myself as a colonizer. I have started to talk, though somewhat quietly and tentatively, as the "me" thoroughly schooled in the habits of repressive erasure would really rather continue to not-talk. I have started to know, though mostly what I know is that I do not know. I do not know what this tentative talking/knowing might, or might not, lead to.

While I cannot be sure of exactly what will eventuate from talking/knowing, the work of writers in the field of critical autoethnography suggests that it will lead to something, since critical autoethnography "is not just about reflection, but the politics involved in reflections" (Morsi 2021, p. 511). For those colonized, autoethnography can be "a liberatory project invested in critically questioning intersecting power dynamics in cultural lives and individual experiences" (Iosefo et al. 2020, p. 2); for the settler-colonizer, autoethnography compels serious thinking about their roles in colonization (past and present) by connecting "very big stories" with "very little stories" (Shaw 2021a, p. 3). Morsi, writing from the position of being Muslim in Aotearoa New Zealand, explains that writing autoethnography is transformative since it is an act, "a process that transforms its bearer through its very action" (Morsi 2021, p. 511): "In this way, the act of writing auto-ethnography involves a kind of temporary eclipse of old subjectivity that gives birth to a new possibility. It is a writing that annihilates me as a knowing subject and in its place something else is reborn. To act is transformative." (Morsi 2021, p. 511). Talking will lead to knowing, and knowing is the precondition of action.

Funding: This research received no external funding.

Institutional Review Board Statement: Not applicable.

Informed Consent Statement: Not applicable.

Acknowledgments: Several people have made important contributions to this paper. I am indebted to the academic and intellectual work of Hugh Campbell, Avril Bell, and Richard Shaw-their thought has been important in developing my own ideas. I have cited their work but would also like to thank them for their support, encouragement and stimulating conversations. Not everyone who has contributed to my thinking is citable, and so I would also like to acknowledge and thank April 
Bennett and Matt Wynward for many stimulating and challenging discussions. The first draft of this paper was written at a writing retreat in Wanaka, and I would like to thank Hugh Campbell and Marion Familtonco for their hospitality, friendship, and support. I would also like to thank the anonymous reviewers for their engagement with my paper and their insightful questions.

Conflicts of Interest: The author declares that there is no conflict of interest.

\section{Notes}

LINZ is Land Information New Zealand, the government agency which holds land title records

2 The absence of mentions of my mother, my grandmother etc. is deliberate. In my family, farms were owned by men and passed on to men. Men were farmers, women were farmers' wives. The names of men were associated with particular farms, and women were rarely legal owners of land.

3 Following Hugh Campbell (2021) I deliberately use "New Zealand" rather than Aotearoa or Aotearoa/New Zealand when referring to this time period to signal the hegemony of New Zealand as a settler state where Māori were excluded and invisibilised.

4 This term is contentious among the descendants of white settlers. Whether a white person adopts or rejects the term Pākehā as an identifier tends to signal something about their position with regards to the place of Māori in the nation. Here I use it following Spoonley's explanation (Spoonley 1993, p. 57), that Pākehā means a white person, probably of Anglo descent, who grew up in New Zealand or Aotearoa New Zealand and whose location in that place has shaped their life experiences and subjectivities, whether they acknowledge this or not. To this I add Fitzpatrick et al.'s definition of Pākehā: "an indigenous term used in New Zealand to describe the descendants of colonial settlers" (Fitzpatrick et al. 2021, p. 461) as their definition names colonisation as a critical, if again often unacknowledged, aspect of being Pākehā.

5 In 1939 about 9\% of the land of the North Island was in Māori ownership; by 2000 this had been reduced to $4 \%$ (New Zealand History n.d., https:/ / nzhistory.govt.nz/media/interactive/maori-land-1860-2000, accessed on 21 December 2021).

6 Tukutuku panels are a form of traditional Māori art. They take the form of lattice-work panels and are used on the walls of wharenui, or meeting houses. They are not simply decorative but convey complex meaning. Traditionally they are made of wooden stakes and rods woven together with flax to make patterns (Māori Dictionary n.d., https:/ / maoridictionary.co.nz/ search?keywords=tukutuku, accessed on 21 December 2021).

7 Poi are balls on strings which are whirled and swung with songs and music (https://maoridictionary.co.nz/search?idiom= \&phrase=\&proverb=\&loan=\&histLoanWords=\&keywords=poi, accessed on 21 December 2021).

8 Tī rākau, or stick games, involve a number of players kneeling in front of each other throwing sticks to each other in time to music (https:/ / maoridictionary.co.nz/search?idiom=\&phrase=\&proverb=\&loan=\&histLoanWords=\&keywords=stick+games, accessed on 21 December 2021). I call them stick games not tī rākau because I didn't know that word then.

9 The Parihaka story should not really be in a footnote, as it is not a footnote to Taranaki history. However, when I was young it was (shamefully) a footnote to my history, so I footnote it here. The settlement of Parihaka was founded in the mid 1860s as a response to colonisation. Led by Te Whiti-o-Rongomai and Tohu Kākahi, of Taranaki and Te Ātiawa iwi, the settlement attracted Māori from around the country, and became a center of non-violent resistance. In May 1879 when the government moved to settle land that had been confiscated in the 1860s, the people from Parihaka responded with a campaign of non-violent resistance, ploughing and fencing land being occupied by settler-colonisers. Several hundred protesters were arrested and imprisoned without trial (indeed, legislation was passed specifically legalising the suspension of habeas corpus for the ploughers and the fencers). A hāngi is a traditional method of food preparation. Stones are heated, a pit is prepared and the food is cooked in baskets over those stones, covered in soil. On November 51881 some 1600 volunteers and members of the Armed Constabulary invaded Parihaka, arresting Te Whiti and Tohu, destroying the settlement and dispersing the occupants. The people of Parihaka responded to this violence with non-violence. Parihaka was rebuilt after the invasion and destruction and remains a powerful symbol of Māori resistance. As Buchanan writes: "The Parihaka story is simultaneously a story of war and a story of peace, a narrative of Māori destruction and a narrative of Māori survival" (Buchanan 2009, p. 12). Parihaka carries enormous symbolic meaning in Aotearoa New Zealand-the history, the place, and the name are iconic. For histories of Parihaka see Buchanan (2009), Keenan (2015), Riseborough (1989) and Scott (1975). Pākehā at times co-opt the story of the Parihaka passive resistance as part of a national narrative that asserts that New Zealand was first in lots of good things (votes for women, old age pensions, for example). In this case, we beat Ghandi to passive resistance. Focusing narrowly on resistance (as opposed to violent colonisation) allows Pākehā (such as myself in my childhood story) to simultaneously imagine and claim both Te Whiti and pioneer-settlers as symbolic ancestors.

10 I don't think I knew the word urupa then, so I am when reflecting on my knowledge I use the words I would likely have used at the time. As with much else in this paper, my lack of knowledge of Te Reo points to my not-knowing.

11 In his work on speech acts philosopher of language J.L. Austin defines a perlocutionary speech act as one which has effects on its recipients, "its consequences (intentional or non-intentional) on the feelings, thoughts, or actions of the participants" (Internet Encyclopedia of Philosophy n.d., https:/ /iep.utm.edu/austin/, accessed on 21 December 2021). 
See, for example, the series of articles on decolonising autoethnography in Cultural Studies "Critical Methodologies», vol. 18, 2018; and Atay (2021). For writing on autoethnography as a decolonizing methodology, see, for example, Iosefo (2018), Iosefo et al. (2020), Morsi (2021) and Whitinui (2014).

Deploying a nameless Māori friend is problematic, but I have chosen not to name her to protect her privacy.

14 I went to visit Dad after writing the first draft of this paper and I asked him again about the house across the road and who had lived there, and in the way of people with dementia sometimes this time he remembered. My memory was wrong. It was Johnny Mitchell who lived across the road, not Johnny Boardman. Johnny Boardman lived further up the road and was Pākehā. Dad told me that Grandad and Johnny Mitchell were great friends, and that Johnny used to come to Morris family occasions and would bring the kids lollies. He was a really nice man, Dad said. He was also a very good mechanic, very good with tractors. And he had a big car which he used to take people to town [New Plymouth] in, kind of like a taxi. I asked Dad what Māori family Johnny Mitchell had belonged to, and suggested a local name. But he didn't know/couldn't remember.

15 Wolfe argues that "Settler colonialism is inherently eliminatory but not invariably genocidal" (Wolfe 2006, p. 387). Instead, elimination takes multiple forms, including most critically, for Wolfe, the alienation of indigenous land (Wolfe 2006, p. 402). Elimination is in some places and at some times repressive and reliant on the use of force, and at other times and places the logic takes forms such as assimilation and the use of law.

16 "To illustrate the extent of leasing, when a review was made in 1912,193,996 acres remained as Taranaki Maori reserves. Of that, 120,110 acres were held by Europeans under perpetual leases, 18,400 acres were held by Europeans under 30-year leases, 24,800 acres were held by Maori under occupation licences, 25,798 acres were held as 'papakaingas or commonages', and 4890 acres were in various tenures" (Waitangi Tribunal 2002, p. 258).

\section{References}

Atay, Ahmet. 2021. Translation and Tango: Decolonizing Autoethnography. In Handbook of Autoethnography. Edited by Tony E. Adams, Stacy Holman Jones and Carolyn Ellis. New York: Routledge, pp. 295-302.

Bell, Avril. 2017. Moving Roots: A "small story" of settler history and home places. Qualitative Inquiry 23: 452-57. [CrossRef]

Bell, Avril. 2020. Reverberating Historical Privilege of a "Middling" Sort of Settler Family. Genealogy 4: 46. [CrossRef]

Bourdieu, Pierre. 2002. Masculine Domination. Palo Alto: Stanford University Press.

Buchanan, Rachel. 2009. The Parihaka Album: Lest We Forget. Wellington: Huia Publishers.

Campbell, Hugh. 2021. Farming Inside Invisible Worlds: Modernist Agriculture and Its Consequences. London and New York: Bloomsbury Academic.

Campbell, Hugh, and William Kainana Cuthers. 2021. Heather's Homestead/Marotahei: The Invasion of the Waikato and Ways of Knowing our Past in Aotearoa New Zealand. Genealogy 5: 101. [CrossRef]

Chawla, Devika, and Ahmet Atay. 2018. Introduction: Decolonizing Autoethnography. Cultural Studies «Critical Methodologies» 18: 3-8. [CrossRef]

Connerton, Paul. 2008. Seven Types of Forgetting. Memory Studies 1: 59-71. [CrossRef]

Dutta, Mohan J. 2018. Autoethnography as Decolonization, Decolonizing Autoethnography: Resisting to Build Our Homes. Cultural Studies «Critical Methodologies» 18: 94-96. [CrossRef]

Ellis, Carolyn. 1999. Heartfelt Autoethnography. Qualitative Health Research 9: 669-83. [CrossRef]

Fassin, Didier. 2014. The Parallel Lives of Philosophy and Anthropology. In The Ground Between: Anthropologists Engage Philosophy. Edited by Michael Jackson, Arthur Kleinman and Bhrigupati Singh. Durham and London: Duke University Press, pp. 50-70.

Fitzpatrick, Esther. 2018. A Story of Becoming: Entanglement, settler ghosts, and postcolonial counterstories. Cultural Studies «Critical Methodologies» 18: 43-51. [CrossRef]

Fitzpatrick, Esther, Mohamed Alansari, Fetaui Iosefo, and Melinda Webber. 2021. A Year of Encounters with Privilege. In Handbook of Autoethnography. Edited by Tony E. Adams, Stacy Holman Jones and Carolyn Ellis. New York: Routledge, pp. 461-71.

Hage, Ghassan. 1998. White Nation: Fantasies of White Supremacy in a Multicultural Society. Annandale: Pluto Press.

Hancock, Frances. 2020. Becoming and Being Irish-Pākehā: Crafting a narrative of belonging that inspirits indigenous-settler relationships. Genealogy 4: 113. [CrossRef]

Internet Encyclopedia of Philosophy. n.d. John Langshaw Austin. Available online: https://iep.utm.edu/austin/ (accessed on 21 December 2021).

Iosefo, Fetaui. 2018. Scene, Seen, Unseen. In Questions of Culture in Autoethnography. Edited by Phiona Stanley and Greg Vass. London: Routledge, pp. 69-79.

Iosefo, Fetaui, Stacy Holman Jones, and Anne Harris, eds. 2020. Introduction: Critical Autoethnography and/as Wayfinding in the Global South. In Wayfinding: Critical Autoethnography. London: Routledge.

Keenan, Danny. 2015. Te Whiti o Rongomai and the Resistance of Parihaka. Wellington: Huia Publishers.

Māori Dictionary. n.d. Available online: https:/ / maoridictionary.co.nz (accessed on 21 December 2021).

Morsi, Yassir. 2021. Using "Auto-Ethnography to Write about Racism". In Handbook of Autoethnography. Edited by Tony E. Adams, Stacy Holman Jones and Carolyn Ellis. New York: Routledge, pp. 505-12.

New Zealand History. n.d. Māori Land Loss, 1860-2000. Available online: https:/ /nzhistory.govt.nz/media/interactive/maori-land1860-2000 (accessed on 21 December 2021). 
Riseborough, Hazel. 1989. Days of Darkness: Taranaki 1878-1884. Wellington: Allen \& Unwin.

Scott, Dick. 1975. Ask That Mountain: The Story of Parihaka. Dunedin: Reed.

Shaw, Richard. 2021a. A Tale of Two Stories: Unsettling a settler family's history in Aotearoa New Zealand. Genealogy 5: 26. [CrossRef]

Shaw, Richard. 2021b. The Forgotten Coast. Palmerston North: Massey University Press.

Sleeter, Christine E. 2011. Becoming White: Reinterpreting a family story by putting race back into the picture. Race, Ethnicity and Education 14: 421-33. [CrossRef]

Sleeter, Christine E. 2016. Critical Family History: Situating family within contexts of power relationships. Journal of Multidisciplinary Research 8: 11-23.

Sleeter, Christine E. 2020. Critical Family History: An introduction. Genealogy 4: 64. [CrossRef]

Spoonley, Paul. 1993. Racism and Ethnicity, rev.ed. Oxford: Oxford University Press.

Waitangi Tribunal. 2002. Taranaki Report: Kaupapa Tuatahi. Wellington: The Tribunal.

Whitinui, Paul. 2014. Indigenous Autoethnography: Exploring, engaging, and experiencing "self" as a native method of inquiry. Journal of Contemporary Ethnography 43: 456-87. [CrossRef]

Wolfe, Patrick. 2006. Settler Colonialism and the Elimination of the Native. Journal of Genocide Research 8: 387-409. [CrossRef] 